\begin{tabular}{|l|l|l||}
\hline \multicolumn{2}{|c|}{ PublisherInfo } \\
\hline \hline PublisherName & $:$ & Palgrave Macmillan UK \\
\hline \hline PublisherLocation & $:$ & London \\
\hline \hline PublisherImprintName & $:$ & Palgrave Macmillan \\
\hline
\end{tabular}

\title{
Following the Atkinson Review: the quality of public sector output
}

\begin{tabular}{|l|l|l||}
\hline \multicolumn{2}{|c|}{ ArticleInfo } \\
\hline \hline ArticleDOI & $:$ & $10.1057 /$ palgrave.elmr.1410104 \\
\hline \hline ArticleCategory & $:$ & Feature \\
\hline \hline ArticleFirstPage & $:$ & 22 \\
\hline \hline ArticleLastPage & $:$ & 26 \\
\hline \hline & $:|l| 2007-7-20$ \\
ArticleHistory & $:$ & $\begin{array}{l}\text { RegistrationDate }: 207-7-20 \\
\text { OnlineDate } \quad: \quad 2007\end{array}$ \\
\hline \hline ArticleCopyright & $:$ & Crown copyright2007 \\
\hline \hline
\end{tabular}


Martin Weale, ${ }^{\text {Aff1 }}$

Aff1 National Institute of Economic and Social Research

\section{Addresses two of the key issues raised by the Atkinson Review: quality adjustment and the use of value weights.}

The UK Centre for the Measurement of Government Activity has made substantial progress in the measurement of public service output and inputs, publishing a series of productivity articles, but inevitably there is room for more work,particularly in the measurement of the quality of both outputs and inputs.

This article addresses two of the key issues raised by the Atkinson Review - quality adjustment and the use of value weights. The benefit of addressing quality issues in the context of conventional index number formulae is shown. Thisleads to smaller quality adjustments than some past work on public sector output has suggested. It is demonstrated that, without the use of value weights, it is not always possible to make quality adjustments. Nevertheless, where value weights cannot be based on marketinformation, they may be difficult to identify and care will be needed in identifying changes to relative values.

Misc

The Full Text of this article can be found on the National Statistics website (http://www.statistics.gov.uk/elmr/07_07/downloads/ELMR_July07_Weale.pdf). 